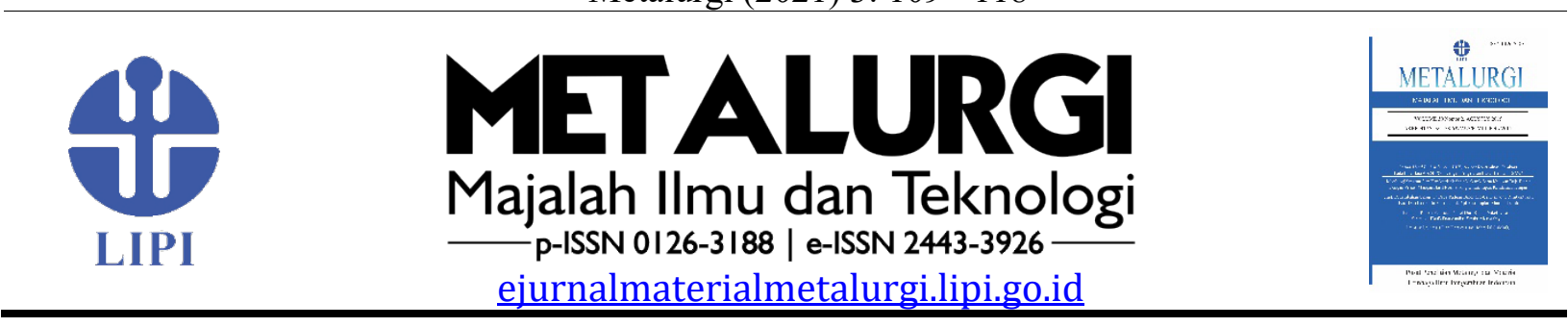

\title{
The EFfect of Precipitation on MicrostruCture AND Corrosion Behaviour of ZK60 SubJeCted to SEVERe Plastic DEFORMATION
}

\author{
Muhammad Rifai ${ }^{a}$, Mujamilah $^{a}$, Hiroyuki Miyamoto ${ }^{b}$ \\ ${ }^{a}$ Center for Science and Technology of Advanced Material, National Research and Innovation Agency \\ Gedung 42, Kawasan PUSPIPTEK Serpong, Banten, Indonesia 15343 \\ ${ }^{b}$ Department Science and Engineering, Doshisha University, Kyotanabe Campus \\ 1-3 Tatara Miyakodani, Kyotanabe-shi, Kyoto-fu, Kyoto, Japan 610-0394 \\ *E-mail: mrifai@batan.go.id
}

Masuk tanggal : 25-10-2021, revisi tanggal : 28-12-2021, diterima untuk diterbitkan tanggal 28-02-2022

\begin{abstract}
Abstrak
Struktur mikro dan perilaku korosi pada ZK60 yang mengalami deformasi plastis sangat tinggi (severe plastic deformation, SPD) telah diselidiki dalam hal proses penghalusan butir dan pembentukan presipitasi. ECAP (equal channel angular pressing) adalah salah satu teknik SPD yang terkenal karena keuntungannya untuk mempromosikan dislokasi dan fragmentasi butir. Billet ZK60 dipotong menjadi bentuk silinder berdiameter $10 \mathrm{~mm}$ untuk aplikasi material yang dapat terurai secara hayati. Proses ECAP dilakukan hingga dua lintasan dengan Route $\mathrm{Bc}$ pada proses temperatur $250^{\circ} \mathrm{C}$. Uji kekerasan mikro dilakukan pada logam ZK60 olahan ECAP, dan pengamatan struktur dilakukan dengan mikroskop optik dan mikroskop elektron transmisi. Perilaku korosi material diselidiki melalui kurva polarisasi anodik. Proses ECAP mendorong akumulasi dislokasi secara efisien dan pembentukan struktur berbutir sangat halus. Hal ini dapat meningkatkan karakteristik sifat mampu bentuk dari ZK60. Kekerasan juga menunjukkan peningkatan yang signifikan selama proses ECAP karena tingkat deformasi yang tinggi. Perilaku korosi dan pengamatan struktur mikro selama proses ECAP menunjukkan korelasi yang menyimpulkan bahwa penghalusan butir dan pembentukan presipitasi mempengaruhi sifat elektrokimia. Elemen paduan seperti $\mathrm{Zn}$ dan $\mathrm{Zr}$ mempromosikan film pelindung untuk korosi karena kemampuannya untuk perlindungan pitting. ECAP meningkatkan pembentukan presipitasi untuk ketahanan terhadap korosi, keseragaman struktur mikro dan sifat mampu bentuk material.
\end{abstract}

Kata Kunci: Proses deformasi plastis sangat tinggi, ZK60, presipitasi, korosi

\begin{abstract}
Microstructure and corrosion behavior of ZK60 subjected to SPD (severe plastic deformation) has been investigated in terms of grain refinement process and precipitation formation. ECAP (equal channel angular pressing) is one of the well-known SPD techniques due to its advantages to promote dislocation and grain fragmentation. ZK60 billet was cut to a $10 \mathrm{~mm}$ diameter cylindrical shape for biodegradable material application. ECAP process was carried out up to two passes by Route Bc at $250{ }^{\circ} \mathrm{C}$ temperature process. Microhardness test was performed at ECAP processed sample, and the microstructural observation was carried out using an optical microscope and transmission electron microscope. The corrosion behavior of the material was investigated using an anodic polarization curve. The ECAP process promotes dislocation accumulation efficiently and ultrafine-grained structure formation. It may improve the formability characteristic of ZK60. The hardness also showed significant increment during the ECAP process due to the high level of deformation. Corrosion behaviors and microstructure observation during the ECAP process showed a correlation that concluded that grain refinement and precipitation formation influenced the electrochemical properties. The alloying element such as $\mathrm{Zn}$ and $\mathrm{Zr}$ promoted the protective film for corrosion due to their ability for pitting protection. ECAP improved the precipitation formation for corrosion resistance, microstructure uniformity, and material formability.
\end{abstract}

Keywords: Severe plastic deformation process, ZK60, precipitation, corrosion 


\section{INTRODUCTION}

Biomaterial application has been investigated rapidly due to high demand in the industrial health sector. Several biomaterial candidates are titanium [1]-[3], stainless steel, and alloy material [4]-[6]. The prospect biomaterial can be used to replace the damage of human body parts related to specific purposes [1]-[2]. There are several unwanted characteristics of biomaterial, such as inflammatory and irritation. Magnesium and magnesium alloys have been investigated to solve this problem due to their biodegradable characteristics [7]-[11]. This material can support the damaged tissue and control the healing time of body parts due to its good biocompatibility and excellent response to simulated body fluid [8],[10]. Magnesium alloys have been used for the industrial sector such as automotive and electronics due to high strength, lower density, and good formability [7]-[11]. It also can be used as a biodegradable biomaterial implant due to its non-toxic behavior. Still, magnesium alloys have several disadvantages, such as difficulty to be processed at low temperature due to its low melting points and crystal structure. The magnesium alloys also show low corrosion resistance and are non-reactive to alkaline metals [10]-[11].

Magnesium alloy can be tolerated in the human body and sent out safely due to the degradation level of the materials. However, the corrosion rate of magnesium is faster than other materials, such iron alloy as a highly active material, and the gas bubbles problem has occurred during the corrosion, which might influence the human body due to high inflammatory to the tissue [9],[11]. Magnesium alloys were proposed to improve the material's properties, but they have lower strength and less inert; therefore, it needs to be improved by materials treatments. High strength, good ductility and degradation control of magnesium alloy are required in the cardiovascular application [12]-[16]. Elements additions and material treatments are several ways to get the specific target of the material application, which influences materials' strength and corrosion behaviour. The magnesium alloys exhibited dislocation motions due to the limitation of the slip plane [8],[10]-[11],[17]. This behaviour will be influenced by plastic deformation applied to the material [17]. Based on theoretical slip systems [18], the plastic deformation will reach homogeneous behaviour after applied on more than four slip planes; however, the magnesium alloy has a HCP (hexagonal closed pack) crystal structure which basal slip systems. This characteristic shows high ductility at room temperature due to the twinning effect of plastic deformation on the material.

The SPD (severe plastic deformation) is well known to produce UFG (ultrafine-grained) structures due to the grain refinement process [19]. This technique can reduce the grain size below two micrometres with low cycles by the SPD process [19]-[20]. The SPD process will be used on magnesium alloy to overcome its disadvantages as a biodegradable biomaterial [17]-[20]. The grain refinement process by the SPD technique shows a unique microstructure evolution and corrosion behaviour among hightemperature metallic materials [17]-[18]. The ECAP (equal channel angular pressing) as the SPD technique exhibits an efficient process to produce UFG structure material, especially for biomaterial application [18].

Controlling the mechanical and electrochemical properties can be done by material processing such as the ECAP process. The ECAP process promotes high strength and homogeneous structure by precipitation formation [21]-[22]. The ECAP process also influences the mechanical properties and corrosion behaviour of metallic material, especially magnesium alloys [21]-[23]. Most researchers have intended this matter [21]-[23], especially on magnesium alloy corrosion behaviour, but the biodegradable behaviour has not been explained adequately. Several parameters that influence the corrosion behaviour are microstructure, temperature and $\mathrm{pH}$ value [24]-[27].

ZK60 is a good biomaterial candidate for cardiovascular application due to its good biocompatibility and biomaterial requirements. ZK60 contains Zn and Zr, which can be absorbed into the human body without affecting the organs [24]-[27]. This alloying element can improve the corrosion resistance and mechanical properties. ECAP is used to carry out the SPD process due to their excellent characteristic to form the metallic material, especially on ZK60 [24]. ECAP promotes a high deformation level equal to almost one equivalent strain and generates UFG efficiently. No publication discussed the corrosion behaviour of ZK60 in the view precipitation formation in detail. This work aims to study and investigate the effect of microstructural evolution on the corrosion behaviour of magnesium alloy ZK60 subjected ECAP process in terms of grain refinement and fine particles appearance, which focuses on biomaterial implant application. 


\section{Materials ANd Methods}

The magnesium alloy of ZK60 was used in the ECAP (equal channel angular pressing) process. The billet's dimension was cut $10 \mathrm{~mm}$ diameter and $55 \mathrm{~mm}$ length, and then it was heattreated at $350{ }^{\circ} \mathrm{C}$ for 24 hours. The ECAP process was carried at $110^{\circ}$ inner angle and the billet was processed by route $\mathrm{Bc}$ up to two passes with the pressing speed of $10 \mathrm{~mm} /$ minutes at $250{ }^{\circ} \mathrm{C}$. The ECAP die was equipped with four heater pins, which can distribute the heat at all parts of the ECAP die. The billets were swab with lubricants to avoid some friction during the ECAP process. The ECAP process was carried out using Autograph $500 \mathrm{kN}$. Route $\mathrm{Bc}$ was done by rotating the billet as $90^{\circ}$ every passing number. The mechanical properties of solution treatment and ECAP processed sample were measured using the Vickers hardness test on the transverse plane.

The microstructure was observed using optical microscope and TEM (transmission electron microscope) at the transverse plane. The corrosion behaviour was measured using a potentiodynamic polarization graph. The threeelectrode method, which contains reference electrodes of platina, $\mathrm{Ag} / \mathrm{AgCl}$ and saturated $\mathrm{KCl}$, was used to evaluate the corrosion behaviour (Hokuto HZ5000).

\section{Results}

As Figure 1 shows the ECAP (equal channel angular pressing) processed billets up to two passes, (a) solution treatment, (b) one pass and (c) two passes ECAP. The dimension of billets did not change in length and diameter after the ECAP process. The ECAP process on ZK60 was carried out at higher than recrystallization temperature. The processing temperature-induced faster grain refinement and good formability of material during the ECAP process.

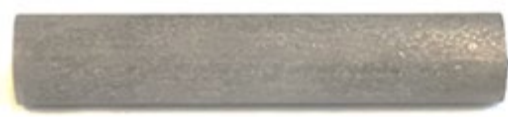

(a)

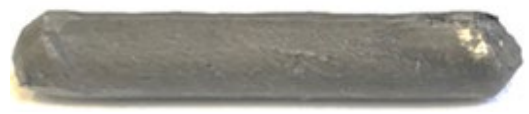

(b)

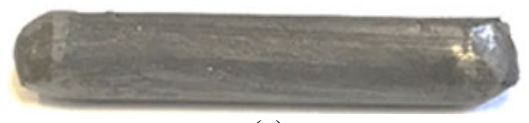

(c)

$10 \mathrm{~mm}$

Figure 1. ECAP sample appearance of (a) as-solution treated, (b) one pass ECAP, and (c) two passes ECAP

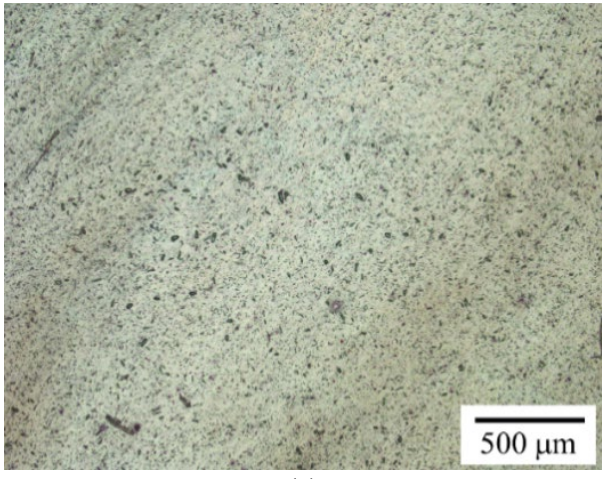

(a)

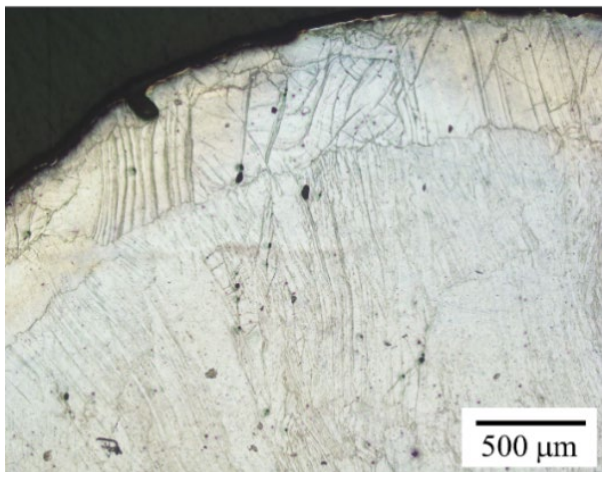

(b)

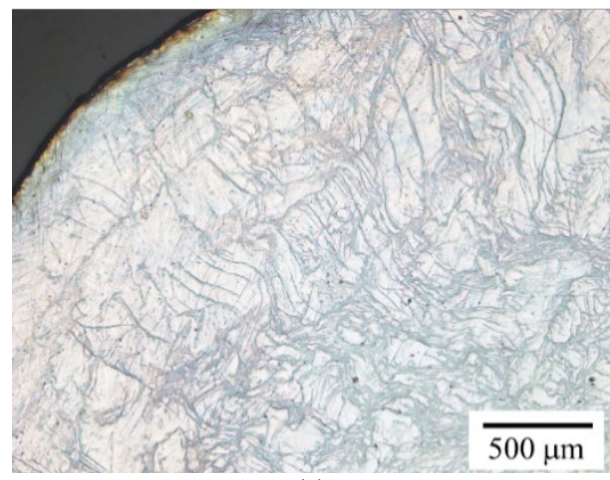

(c)

Figure 2. Optical microscope observation on (a) as-solution treated, (b) one pass ECAP, and (c) two passes ECAP.

The grain size of the solution-treated sample is around $60 \mu \mathrm{m}$, as seen in Figure 2. After the first ECAP pass, the outer part seems more deformed than that of the inner parts and the grain size decrease around $20 \mu \mathrm{m}$. The deformation influences all the part of billets due to high deformation after two passes ECAP and the increment amount of crystal defect during the second ECAP process. The billets also showed high shear stress in the ZK60 after ECAP. 


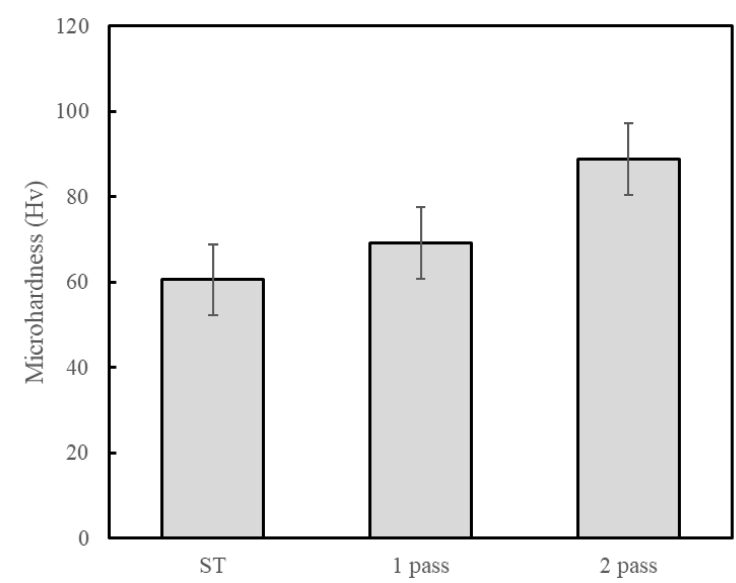

Figure 3. Microhardness of as-solution treated, one pass ECAP, and two passes ECAP

Figure 3 shows the microhardness of solution treated, one pass and two passes of ZK 60. The hardness increases with increasing the pass number of ECAP due to deformation and shear stress on the sample during the ECAP process. The hardness distribution seems to occur due to the deformation level at the billet. In the first pass of ECAP, the deformation appears initially in the edge of the ECAP process due to localization of deformation. After two passes, the deformation turns the structure more homogeneous in the ZK60 due to the short strain hardening step during the ECAP process. The saturation is happened in the magnesium sample due to fast hardening [18], and it seems the magnesium alloy also exhibited a similar hardness behaviour. The ECAP process on magnesium activated the grain boundary due to the creep effect at room temperature. The creep effect is correlated to dwell time at hardness testing. It also confirmed that the hardness of ECAP processed billets of ZK60 is associated with the texture evolution of ZK60 during the ECAP process. It also confirmed that the texture showed softening during grain refinement at the high-temperature ECAP process [24].

Figure 4 shows the structure of two passes ECAP processed samples using TEM (transmission electron microscope). The average grain size is reduced to nanometer area, and delicate particle appearances can be seen clearly due to recrystallization during the ECAP process at $523 \mathrm{~K}$. The TEM observation was carried in the bright field, revealing the grain boundary junctions, the fine particles and dislocation motions.

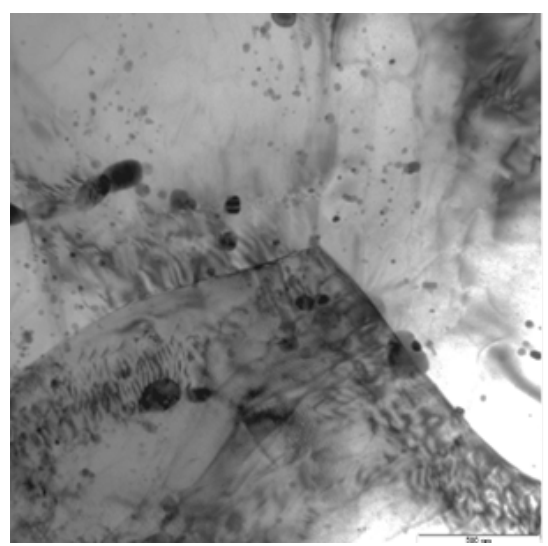

(a)

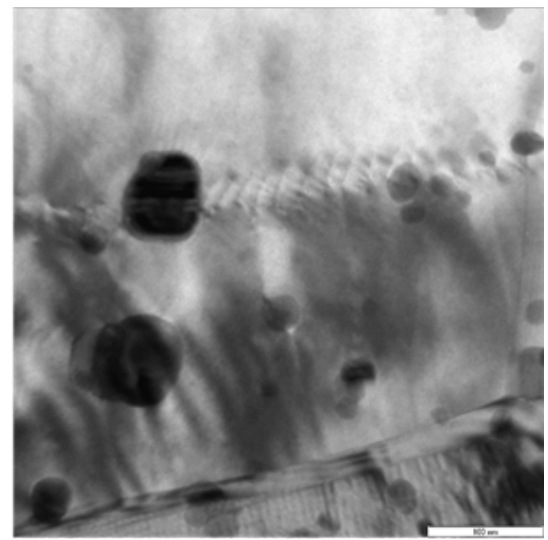

(b)

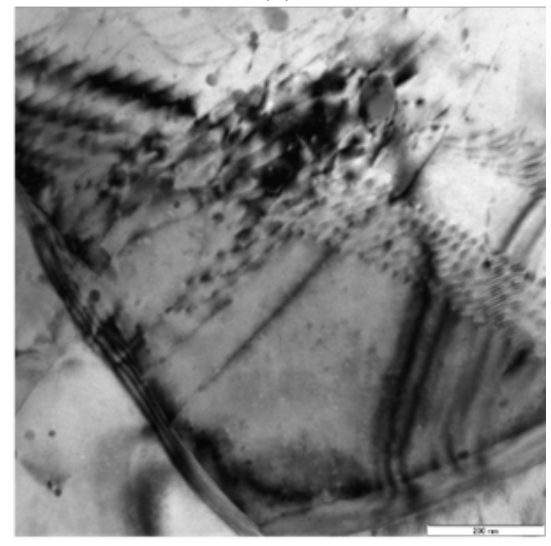

(c)

Figure 4. Transmission electron image of (a) grain boundary image; (b) dislocation appearance near precipitate; and (c) dislocation inside grain

Figure 5 shows various second phase particle appearance after the ECAP process. Due to the high deformation applied at billets, the second phase particles break up into fine particles. Figure 6 shows the EDS (energy-dispersive Xray spectroscopy) result of the fine particles containing $\mathrm{O}, \mathrm{Mg}, \mathrm{Cu}, \mathrm{Zn}$, and $\mathrm{Zr}$, which is associated with element of ZK60. 


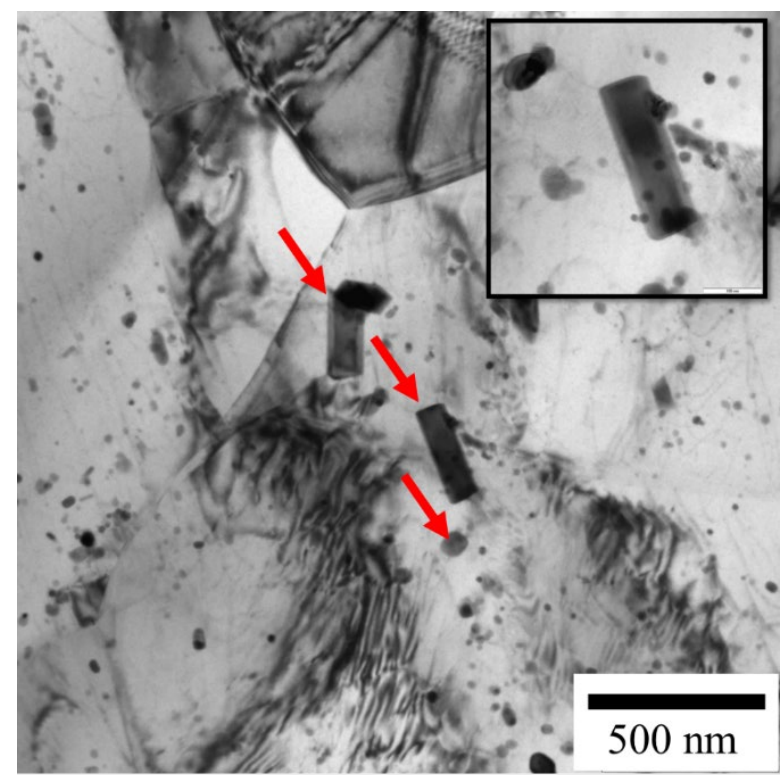

Figure 5. Precipitation appearance inside grain in bar and round shape, as pointed by red arrow

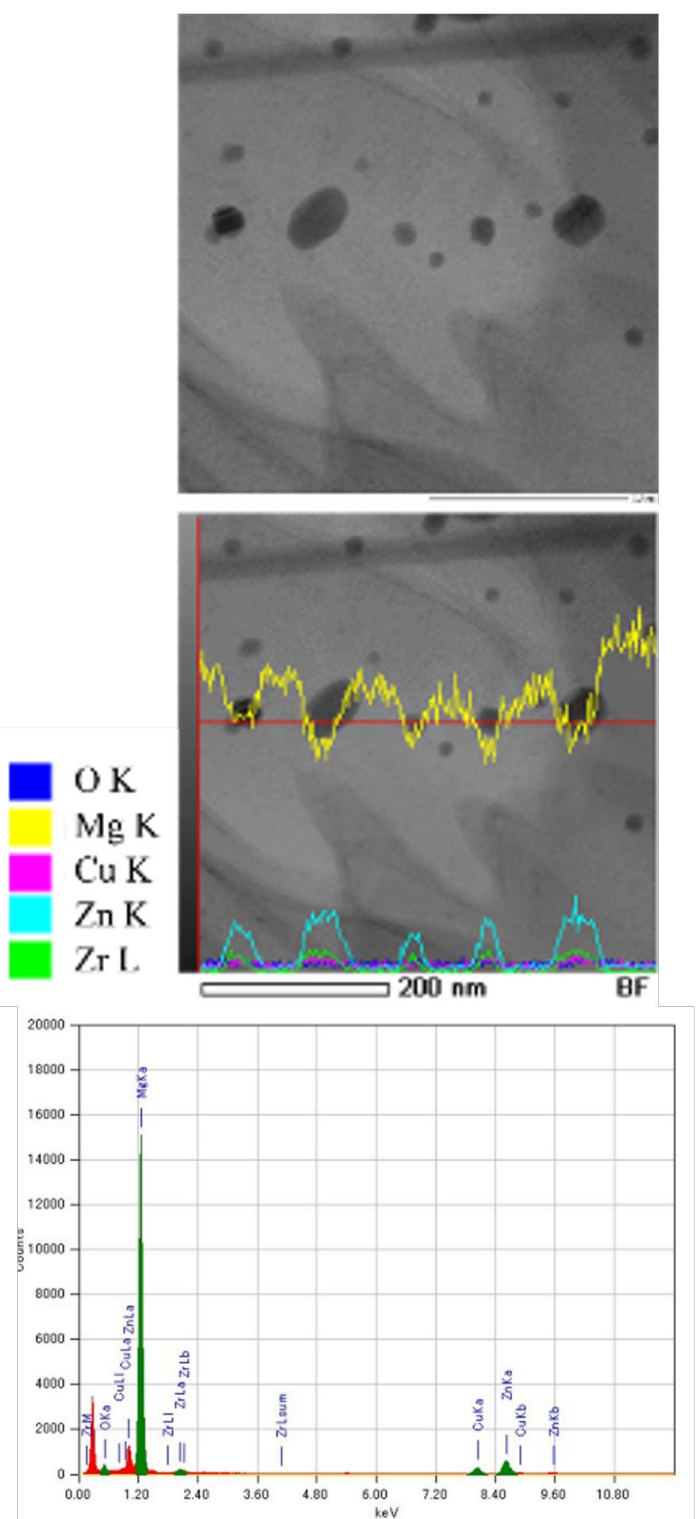

Figure 6. TEM-EDS analysis in round particle with consist of $\mathrm{O}, \mathrm{Mg}, \mathrm{Cu}, \mathrm{Zn}$, and $\mathrm{Zr}$

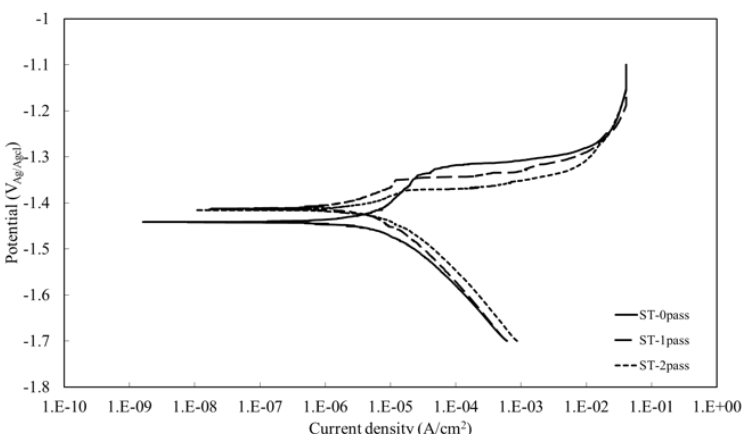

Figure 7. Potentiodynamic polarization curve of as-solution treated, one pass ECAP, and two passes ECAP

Figure 7 shows the anodic potentiodynamic graph of solution treated and ECAP process sample drawn by potential and current density. The corrosion potential of ZK60 shows positive value due to the protective layer from the other elements [28]-[31]. After the ECAP process, the protective layer decreases eventually due to high stress and deformation on the sample. By increasing the anodic value, the protective layer may disappear in all samples due to magnesium characteristics.

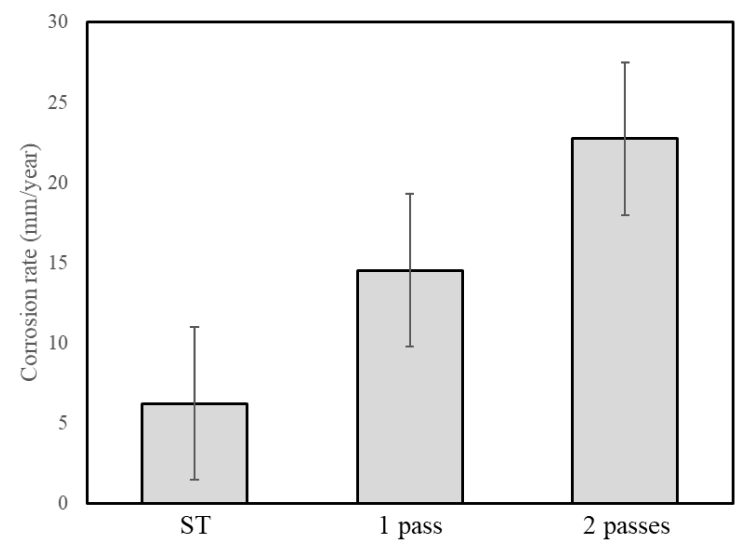

Figure 8. Corrosion rate of as-solution treated, one pass ECAP, and two passes ECAP

The protective layer can be broken down at a higher potential called pitting potential; however, the protective layer formation is associated by corrosion current density [32]-[35]. Previous research mentioned that influence of $\mathrm{Zn}$ alloying element at magnesium matrix showed localization corrosion by forming pitting on the surface of the matrix [33]-[35]. The chlorine solution promoted protective layer break down due to the thickness of the layer, which means the protection of the matrix does not remain efficiently. By treating the material using the ECAP process, it can be used to control the corrosion rate of the materials. This anodic potentiodynamic graph can be used to measure the corrosion rate of materials, as can be seen in Figure 8 . The corrosion current density shows a 
lower value after the ECAP process, which is associated with the corrosion rate of materials. The solution treated sample shows higher corrosion resistance than ECAP processed sample due to zinc and zirconium at magnesium matrix and small amounts of fine particles.

\subsection{Discussion}

The ECAP process is well known to produce grain refinement of metallic material, especially magnesium alloy, which can influence the corrosion behaviour and mechanical properties. The structure evolution was occurred by grain refinement process which the grain size was reduced in to submicrometer, and also associated with the increasing of hardness value. Previous research confirmed that the texture of ECAP processed sample affect the mechanical properties and corrosion behaviour [36]-[38]. The homogeneous structure was achieved at a higher level of deformation by ECAP. The finer particles were appeared on the surface of magnesium alloy due to the breaking up of second phase particles due to the ECAP process. This second phase, finer particles may attribute to a hardness value. The large intermetallic particle distributed uniformly in ECAP processed sample, which can influence the corrosion behaviour, especially the pitting formation. The schematic of structural change can be seen in Figure 9.

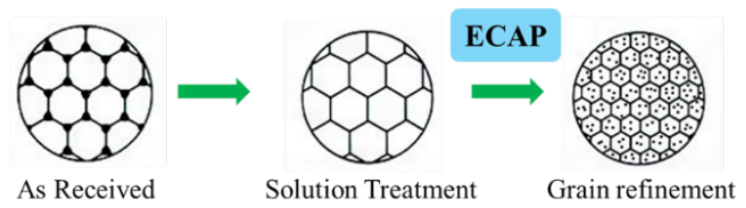

Figure 9. Grain refinement process on pure magnesium through solution treatment.

The corrosion behaviour is affected by structural change due to solution treatment and high deformation level. The hot rolling and highpressure torsion process can also confirm these results, which mentioned lower corrosion resistance due to high deformation levels [39][41]. It can be concluded that the ECAP process of solution treated ZK60 can improve the mechanical properties and modify the corrosion behaviour for biodegradable materials.

\section{Conclusions}

Microstructure and corrosion behaviour of ZK60 subjected to severe plastic deformation (SPD) results can be summarized: Magnesium alloy ZK60 was processed by ECAP, which exhibited microstructure change and higher mechanical properties; however, the corrosion resistance decrease due to an aggressive corrosion environment and a high level of deformation. The homogeneous structure was achieved at a higher deformation level due to the repeatable process at the sample. The deformation process also produces finer grain and second phase particles which affect the hardness value. The corrosion resistance value decreases due to structure change associated with the deformation level.

\section{ACKNOWLEDGEMENT}

The authors would like to express their gratitude for the research funding from RISET PRO program FY 2019.

\section{REFERENCES}

[1] C. Oldani, and A. Dominguez, "Titanium as a biomaterial for implants," Recent advances in arthroplasty., vol. 218, pp. 149-162, 2012. ISBN 978-953-307-990-5.

[2] M. Kulkarni, A. Mazare, P. Schmuki, and A. Iglič, "Biomaterial surface modification of titanium and titanium alloys for medical applications," Nanomedicine., vol. 111, no. 111, 2014. ISBN 978-1-910086-01-8.

[3] S. Prasad, M. Ehrensberger, M. P. Gibson, H. Kim, and E. A. Monaco Jr, "Biomaterial properties of titanium in dentistry," Journal of oral biosciences., vol. 57, no. 4, pp. 192-199, 2015. Doi: 10.1016/j.job.2015.08.001.

[4] M. Kheirkhah, M. Fathi, H. R. Salimijazi, and M. Razavi, "Surface modification of stainless steel implants using nanostructured forsterite $\left(\mathrm{Mg}_{2} \mathrm{SiO}_{4}\right)$ coating for biomaterial applications," Surface and Coatings Technology., vol. 276, pp. 580-586, 2015. Doi: 10.1016/j.surfcoat.2015.06.012.

[5] E. S. Silva, R. C. Sousa, A. M. Jorge Jr, and O. Balancin, "Hot deformation behavior of an $\mathrm{Nb}$-and $\mathrm{N}$-bearing austenitic stainless steel biomaterial," Materials Science and Engineering: A., vol. 543, pp. 69-75, 2012. Doi: 10.1016/j.msea.2012.02.048.

[6] Z. R. Muslim, and A. A. Abbas, "The effect of ph and temperature on corrosion rate stainless steel 3161 used as biomaterial," Int. J. Basic Appl. Sci., vol. 4, pp. 17-20, $2015 . \quad$ Doi: 10.14419/ijbas.v4i4.5147.

[7] Y. Tan, Y. Liu, and L. Grover, "Effect of phosphoric acid on the properties of magnesium oxychloride cement as a biomaterial," Cement and concrete 
research., vol. 56, pp. 69-74, 2014. Doi: 10.1016/j.cemconres.2013.11.001.

[8] S. E. Henderson, K. Verdelis, S. Maiti, S. Pal, W. L. Chung, D. T. Chou, and A. J. Almarza, "Magnesium alloys as a biomaterial for degradable craniofacial screws," Acta biomaterialia, vol. 10, no. 5, pp. 2323-2332, $2014 . \quad$ Doi: 10.1016/j.actbio.2013.12.040.

[9] M. Nan, C. Yangmei, and Y. Bangcheng, "Magnesium metal-A potential biomaterial with antibone cancer properties," Journal of Biomedical Materials Research Part A., vol. 102, no. 8, pp. 2644-2651, 2014. Doi: 10.1002/jbm.a.34933.

[10] J. Walker, S. Shadanbaz, T. B. Woodfield, M. P. Staiger, and G. J. Dias, "Magnesium biomaterials for orthopedic application: a review from a biological perspective," Journal of Biomedical Materials Research Part B: Applied Biomaterials., vol. 102, no. 6, pp. 1316-1331, 2014. Doi: 10.1002/jbm.b.33113.

[11] A. Tahmasebifar, S. M. Kayhan, Z. Evis, A. Tezcaner, H. Cinici, and M. Koc, "Mechanical, electrochemical and biocompatibility evaluation of AZ91D magnesium alloy as a biomaterial," Journal of Alloys and Compounds., vol. 687, pp. 906-919, 2016. Doi: 10.1016/j.jallcom.2016.05.256.

[12] A. Hideo-Kajita, S. Wopperer, V. B. Seleme, M. H. Ribeiro, and C. M. Campos, "The development of magnesium-based resorbable and iron-based biocorrodible metal scaffold technology and biomedical applications in coronary artery disease patients," Applied Sciences., vol. 9, no. 17, pp. 3527, 2019. Doi: 10.3390/app9173527.

[13] J. Fu, Y. Su, Y. X. Qin, Y. Zheng, Y. Wang, and D. Zhu, "Evolution of metallic cardiovascular stent materials: a comparative study among stainless steel, magnesium and zinc," Biomaterials., vol. 230, pp. 119641, 2020. Doi: 10.1016/j.biomaterials.2019.119641.

[14] F. E. T. Heakal, and A. M. Bakry, "Serum albumin can influence magnesium alloy degradation in simulated blood plasma for cardiovascular stenting," Materials Chemistry and Physics., vol. 220, pp. 3549, 2018. Doi: 10.1016/j.matchemphys.2018.08.060.

[15] C. Chen, J. Tan, W. Wu, L. Petrini, L. Zhang, Y. Shi, and F. Migliavacca, "Modeling and experimental studies of coating delamination of biodegradable magnesium alloy cardiovascular stents," Acs Biomaterials Science \& Engineering., vol. 4, no. 11, pp. 3864-3873, 2018. Doi: 10.1021/acsbiomaterials.8b00700.

[16] H. Kitabata, R. Waksman, and B. Warnack, "Bioresorbable metal scaffold for cardiovascular application: current knowledge and future perspectives," Cardiovascular Revascularization Medicine., vol. 15, no. 2, pp. 109-116, 2014. Doi: 10.1016/j.carrev.2014.01.011.

[17] J. Huot, N. Y. Skryabina, and D. Fruchart, "Application of severe plastic deformation techniques to magnesium for enhanced hydrogen sorption properties," Metals., vol. 2, no. 3, pp. 329-343, 2012. Doi: $10.3390 /$ met2030329.

[18] C. L. Silva, A. C. Oliveira, C. G. Costa, R. B. Figueiredo, M. de Fátima Leite, M. M. Pereira, and T. G. Langdon, "Effect of severe plastic deformation on the biocompatibility and corrosion rate of pure magnesium," Journal of Materials Science., vol. 52, no.10, pp. 5992-6003, 2017. Doi: 10.1007/s10853-017-0835-x.

[19] R. B. Figueiredo, S. Sabbaghianrad, A. Giwa, J. R. Greer, and T. G. Langdon, "Evidence for exceptional low temperature ductility in polycrystalline magnesium processed by severe plastic deformation," Acta Materialia., vol. 122, pp. 322-331, 2017. Doi: 10.1016/j.actamat.2016.09.054.

[20] J. P. Young, H. Askari, Y. Hovanski, M. J. Heiden, and D. P. Field, "Thermal microstructural stability of AZ31 magnesium after severe plastic deformation," Materials Characterization., vol. 101, pp. 9-19, 2015. Doi: 10.1016/j.matchar.2014.12.026.

[21] R. Jahadi, M. Sedighi, and H. Jahed, "ECAP effect on the micro-structure and mechanical properties of AM30 magnesium alloy," Materials Science and Engineering: A., vol. 593, pp. 178-184, 2014. Doi: 10.1016/j.msea.2013.11.042.

[22] P. Minárik, R. Král, and M. Janeček, "Effect of ECAP processing on corrosion resistance of AE21 and AE42 magnesium alloys., Applied Surface Science, vol. 281, pp. 44-48, $2013 . \quad$ Doi: 10.1016/j.apsusc.2012.12.096.

[23] P. Minárik, R. Král, J. Ćížek, and F Chmelík, "Effect of different c/a ratio on the microstructure and mechanical properties in magnesium alloys processed by ECAP," Acta Materialia., vol. 107, pp. 
83-95, 2016.

Doi: 10.1016/j.actamat.2015.12.050.

[24] Y. Yuan, A. Ma, X. Gou, J. Jiang, G. Arhin, D. Song, and H. Liu, "Effect of heat treatment and deformation temperature on the mechanical properties of ECAP processed ZK60 magnesium alloy," Materials Science and Engineering: A., vol. 677, pp. 125-132, 2016. Doi: 10.1016/j.msea.2016.09.037.

[25] P. Minárik, R. Král, J. Pešička, S. Daniš, and M. Janeček, "Microstructure characterization of LAE442 magnesium alloy processed by extrusion and ECAP," Materials Characterization., vol. 112, pp. 1-10, 2016.2 Doi: 10.1016/j.matchar.2015.12.002.

[26] J. Sun, Z. Yang, J. Han, H. Liu, D. Song, J. Jiang, and A. Ma, "High strength and ductility AZ91 magnesium alloy with multi-heterogenous microstructures prepared by high-temperature ECAP and short-time aging," Materials Science and Engineering: A., vol. 734, pp. 485-490, 2018. Doi: 10.1016/j.msea.2018.07.075.

[27] M. Cabibbo, C. Paoletti, P. Minárik, R. Král, and M. Zemková, "Secondary phase precipitation and thermally stable microstructure refinement induced by ECAP on Mg-Y-Nd (WN43) alloy," Materials Letters., vol. 237, pp. 5-8, 2019. Doi: 10.1016/j.matlet.2018.09.107.

[28] E. Mostaed, M. Hashempour, A. Fabrizi, D. Dellasega, M. Bestetti, F. Bonollo, and M. Vedani, "Microstructure, texture evolution, mechanical properties and corrosion behavior of ECAP processed ZK60 magnesium alloy for biodegradable applications," Journal of the Mechanical Behavior of Biomedical Materials., vol. 37, pp. 307-322, 2014. Doi: 10.1016/j.jmbbm.2014.05.024.

[29] K. R. Gopi, H. S. Nayaka, and S. Sahu, "Corrosion behavior of ECAP-processed AM90 magnesium alloy," Arabian Journal for Science \& Engineering., vol. 43, no. 9, 2018. Doi: 10.1007/s13369-018-3203-5.

[30] M. Gholami-Kermanshahi, V. D. Neubert, M. Tavakoli, F. Pastorek, B. Smola, and V. Neubert, "Effect of ECAP processing on corrosion behavior and mechanical properties of the ZFW MP magnesium alloy as a biodegradable implant material," Advanced Engineering Materials., vol. 20, no. 10, pp. 1800121, 2018. Doi: 10.1002/adem.201800121.
[31] G. M. Naik, S. Narendranath, and S. Kumar, "Effect of ECAP die angles on microstructure mechanical properties and corrosion behavior of AZ80 Mg alloy," Journal of Materials Engineering and Performance., vol. 28, no. 5, pp. 26102619, 2019. Doi: 10.1007/s11665-01904080-5.

[32] A. Witecka, A. Bogucka, A. Yamamoto, K. Máthis, T. Krajňák, J. Jaroszewicz, and W. Święszkowski, "In vitro degradation of ZM21 magnesium alloy in simulated body fluids," Materials Science and Engineering: C., vol. 65, pp. 59-69, 2016. Doi: 10.1016/j.msec.2016.04.019.

[33] A. I. Alateyah, T. A. Aljohani, M. O. Alawad, H. A. El-Hafez, A. N. Almutairi, E. S. Alharbi, and W. H. El-Garaihy, "Improved corrosion behavior of AZ31 alloy through ECAP processing," Metals., vol. 11, no. 2, pp. 363, 2021. Doi: 10.3390/met11020363.

[34] D. Song, C. Li, N. Liang, F. Yang, J. Jiang, J. Sun, and X. Ma, "Simultaneously improving corrosion resistance and mechanical properties of a magnesium alloy via equal-channel angular pressing and post water annealing," Materials \& Design., vol. no. 166, pp. 107621, 2019. Doi: 10.1016/j.matdes.2019.107621.

[35] Z. Yang, A. Ma, B. Xu, J. Jiang, and J. Sun, "Corrosion behavior of AZ91 Mg alloy with a heterogeneous structure produced by ECAP," Corrosion Science., vol. 187, pp. 109517, 2021. Doi: 10.1016/j.corsci.2021.109517.

[36] M. Gzyl, A. Rosochowski, S. Boczkal, and L. Olejnik, "The role of microstructure and texture in controlling mechanical properties of AZ31B magnesium alloy processed by I-ECAP," Materials Science and Engineering: A., vol. 638, pp. 20-29, 2015. Doi: 10.1016/j.msea.2015.04.055.

[37] S. Seipp, M. F. X. Wagner, K. Hockauf, I. Schneider, L. W. Meyer, and M. Hockauf, "Microstructure, crystallographic texture and mechanical properties of the magnesium alloy AZ31B after different routes of thermo-mechanical processing," International Journal of Plasticity., vol. 35, pp. 155-166, 2012. Doi: 10.1016/j.ijplas.2012.03.007.

[38] N. Martynenko, E. Lukyanova, V. Serebryany, D. Prosvirnin, V. Terentiev, G. Raab, and Y. Estrin, "Effect of equal channel angular pressing on structure, texture, mechanical and in-service 
properties of a biodegradable magnesium alloy," Materials Letters., vol. 238, pp. 218-221, 2019. Doi: 10.1016/j.matlet.2018.12.024.

[39] J. Stráská, J. Stráský, and M. Janeček, "Activation energy for grain growth of the isochronally annealed ultrafine grained magnesium alloy after hot extrusion and equal-channel angular pressing (EXECAP)," Acta Physica Polonica A., vol. 128, no. 4, 2015.

[40] J. Stráská, M. Janeček, J. Čížek, J. Stráský, and B. Hadzima, "Microstructure stability of ultra-fine grained magnesium alloy AZ31 processed by extrusion and equalchannel angular pressing (EX-ECAP)," Materials Characterization., vol. 94, pp. 69-79, $2014 . \quad$ Doi: 10.1016/j.matchar.2014.05.013.

Y. Tan, W. Li, W. Hu, X. Shi, and L. Tian, "The Effect of ECAP temperature on the microstructure and properties of a rolled rare earth magnesium alloy," Materials., vol. 12, no. 9, pp. 1554, 2019. Doi: $10.3390 / \mathrm{ma} 12091554$. 